\title{
外因性内分泌かく乱物質（いわゆる環境ホルモン） について
}

\section{Endocrine Disruptors}

\author{
小松 一裕 \\ Komatsu, Kazuhiro \\ （財団法人 日本食品分析センター） \\ Japan Food Reseach Laboratories
}

\section{1．外因性内分泌かく乱物質とは何か}

「外因性内分泌かく乱物質（いわゆる環境ホルモン）」 とは“動物の生体内に取り込まれた場合に, 本来その生 体内で営まれている正常なホルモン作用に影響を与兄る 外因性の物質”を意味する. 近年, 内分泌学をはじめと する医学, 野生生物に関する科学, 環境科学等の研究者 ·専門家によって, 環境中に存在するいくつかの化学物 質が，動物の体内のホルモン作用をかく乱することを通 じて, 生殖機能を阻害したり, 悪性腫瘍を引き起こすな どの悪影響を及ぼしている可能性があるとの指摘がなさ れている.これが「外因性内分泌かく乱物質問題」と呼 ばれているものである.

日本の省庁は「外因性内分泌擤乱化学物質」「内分泌 かく乱化学物質」「内分泌かく乱物質」を用いている. 海外では Endocrine Disruptors(EDs), Environmental Endocrine Disruptors, Endocrine-Disrupting Chemicals, Environmental Hormones 等の用語が用いられている. 日本では「環境ホルモン」といら呼称がマスコミに登場 してから世間一般に広まった。

1998年 3 月 IPCS（国際化学物質安全化計画）は「内 分泌かく乱物質とは, 健康な生物, その子孫または小集 団（亜群）において, 内分泌系機能を変化させ, 結果的 に健康に有害影響を及ぼす外因性物質むたは混合物をい 5.」といら実用的定義について合意している.

\section{2. 科学的知見の不十分性}

内分泌かく乱物質問題に関しては, ヒトや野生生物一 の影響を示唆する科学的報告が多くなされているもの の, 報告された異常之原因の因果関係, そらした異常が

本稿は第16回研究集会の特別講演を纏めたものである.
発生するメカニズム等に関しては，いまだ十分には明ら かにされていない、環境中にはヒト拉よび動物のホルモ ン作用をかく乱する物質がいくつか存在する. 今後は, 指摘されているとトや野生生物の異常を検証するために 報告の例数を增や寸こと, 統計的な解析を深めること, 環境污染状況や環境污染を通じたヒトや野生生物への掑 取量の把握, 影響が発現する作用メカニズム解明等のた めの調查・研究を一層深めていくことが求められてい る。また，現在までに指摘されている約70の物質を含め て, より幅広い化学物質について, それが内分泌かく乱 作用を有するのか否か, どの程度の作用力を持つもので あるか等を明らかにする必要がある。

\section{3. 内分泌かく乱物質リスト}

環境庁環境ホルモン戦略計画 SPEED'98でリストし ている化合物は, 約70種あるが，基本的には世界野生生 物基金（WWF）の指摘リストに拠っている（表 1).

ここでは, 規制が必要な残留性有機污染物質と一般化 学物質のらちビスフェノールAについて述べる.

(1) 残留性有機污染物質 (POPs; Persistent Organic Pollutants)

POPs とは難分解性有機化合物のことで食物連鎖を通 して濃縮され, 高次の生物で濃縮が高くなる. POPsに は PCBs, ダイオキシン類, DDT 類, クロルデン類, ヘプタクロルを含む12物質が含まれる.1974年 Rappe らは，これらのPOPsはガスやエアロゾル状態で広域 移動し, 放出源から数千キロ離れた寒冷地域で㠜縮する ことを報告した．その結果として極地の海水を，さらに は野生生物を污染することが示唆された.

ダイオキシンはヒトにとって最も毒性の強い化合物で 非意図的にごみ焼却場, 森林火災, 火山活動で発生する。 哺乳動物を用いた実験では内分泌系への影響として脳下 
日本食生活学会志

表 1 内分泌かく乱物質としてリストされた化学物質

\begin{tabular}{|c|c|}
\hline 用 途 & 化 学 物 質 \\
\hline $\begin{array}{l}\text { 非意図的生 } \\
\text { 成物 }\end{array}$ & 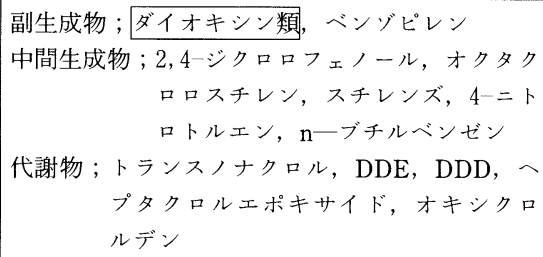 \\
\hline 農薬 & 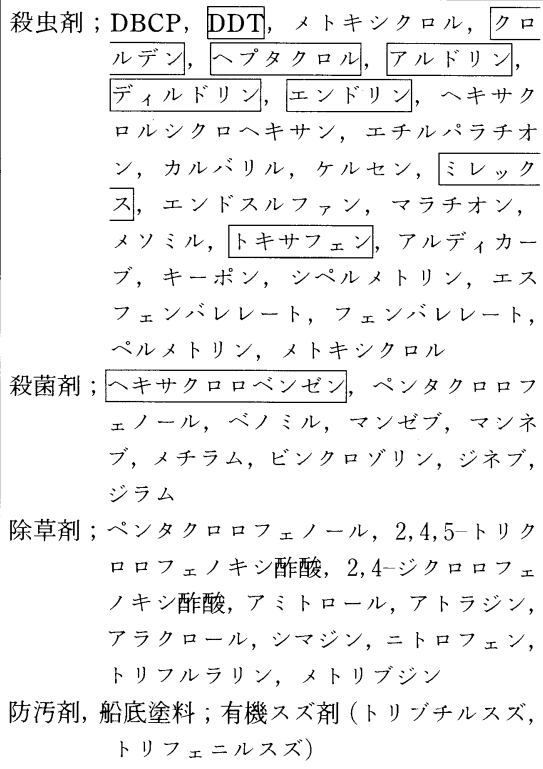 \\
\hline 工業的使用 & 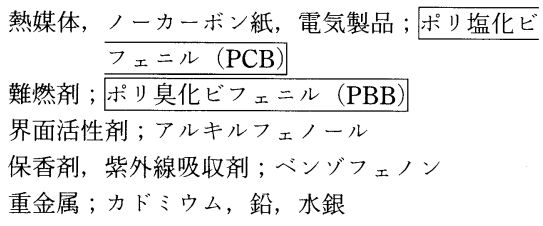 \\
\hline $\begin{array}{l}\text { プラスチッ } \\
\text { ク, 樹脂製 } \\
\text { 造 }\end{array}$ & 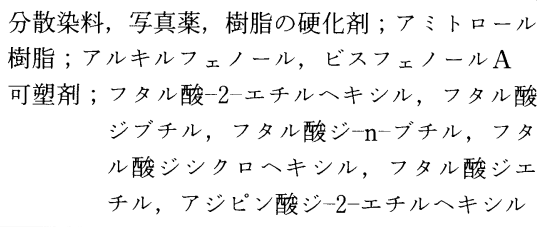 \\
\hline 医療用薬剤 & $\begin{array}{c}\text { 調剤, 避妊薬 ; 閉経時のホルモン凨, DES（ジ } \\
\text { エチルスチルベステロール）, 避 } \\
\text { 妊薬 }\end{array}$ \\
\hline $\begin{array}{l}\text { 植物ホルモ } \\
\text { ン }\end{array}$ & $\begin{aligned} \text { 植物性エストロゲン; } & \text { ダイゼイン,ゲニステイン, } \\
& \text { クメストロール, フォルモ } \\
& \text { ネクンン, バイオカニン } \mathrm{A}\end{aligned}$ \\
\hline
\end{tabular}

参考資料 WWF ホームページリスト，環境庁リスト， OECD 質問状への回答, 奪われし未来

POPs 化合物をOO○で示した.
表 2 平成 8 年度 食品中のダイオキシン類污染実態調査

\begin{tabular}{|c|c|c|c|c|c|c|}
\hline 食品群 & 関東地区 & 関西地区 & 九州地区 & 平均值 & 標準偏差 & 比率 $(\%)$ \\
\hline 1 群(米) & 0.309 & 0.263 & 0.303 & 0.292 & 0.025 & 0.9 \\
\hline 2 群 (穀類·いも類) & 0.146 & 1.201 & 2.810 & 1.386 & 1.342 & 4.4 \\
\hline 3 群(砂糖·菓子) & 1.410 & 1.229 & 0.054 & 0.898 & 0.736 & 2.9 \\
\hline 4 群(油脂) & 1.193 & 1.172 & 0.711 & 1.025 & 0.272 & 3.3 \\
\hline 5 群 (豆·豆加工品) & 0.201 & 0.036 & 0.075 & 0.104 & 0.086 & 0.3 \\
\hline 6 群(果実) & 0.028 & 0.026 & 1.138 & 0.397 & 0.641 & 1.3 \\
\hline 7 群(有色野菜) & 0.189 & 2.591 & 2.555 & 1.778 & 1.377 & 5.7 \\
\hline 8 群(野菜·海藻) & 0.580 & 0.045 & 0.108 & 0.244 & 0.292 & 0.8 \\
\hline 9 群(喏好品) & 0.121 & 0.162 & 0.073 & 0.119 & 0.045 & 0.4 \\
\hline 10群(魚介類) & 28.944 & 23.460 & 11.227 & 21.210 & 9.070 & 67.5 \\
\hline 11群(肉·卵) & 1.456 & 2.068 & 1.228 & 1.584 & 0.434 & 5.0 \\
\hline 12群(乳·乳製品) & 1.904 & 1.948 & 1.038 & 1.630 & 0.513 & 5.2 \\
\hline 13群 (加工食品) & 0.873 & 0.651 & 0.738 & 0.754 & 0.112 & 2.4 \\
\hline 14群 (飲料水) & 0.000 & 0.001 & 0.004 & 0.002 & 0.002 & 0 \\
\hline $\begin{array}{l}\text { 総撕取量 ( } 1 \text { 人/ } \\
1 \text { 日) }\end{array}$ & 37.4 & 34.9 & 22.1 & 31.4 & 8.2 & 100 \\
\hline $\begin{array}{l}\text { 体重当たり摂取量 } \\
\text { (kg 体重/ } 1 \text { 日) }\end{array}$ & 0.75 & 0.70 & 0.44 & 0.63 & 0.17 & \\
\hline
\end{tabular}

単位 : pg 2,3,7,8-TCDD (TEQ), Co- PCB の平均値0.97

ヒトの体重 ; $50 \mathrm{~kg}$

垂体に作用し, 雌ではエストラジオールのレベル減少, 妊娠維持困難, 雄では性行動異常, 生殖能力異常, 精子 形成異常を起こす。をた，子宮内膜症の原因物質として 疑われているが疫学的にはまだ根拠がない，子宮内の暴 露では, 胎児·出生児の生存率低下, 雄の生殖器発達遅 延, 雌性化, 外生殖器の形成異常が起こる. また, 最近 の研究ではダイオキシンが甲状腺レセプターに結合する ことから脳神経系に作用し精神荤滞, 行動障害, 学習障 害の原因物質として疑われている。

WHO は1998年 5 月29日 TDI(耐容一日拱取量)を内 分泌かく乱作用を考慮し、これまでの $10 \mathrm{pg} / \mathrm{kg} / \mathrm{day}$ ら $1-4 \mathrm{pg} / \mathrm{kg} /$ day に引き下げた。この新基準には，コ プラナーPCB を含む. これに伴い, 日本の厚生省, 環 境庁も見直しの検討を開始したところである.

食品のダイオキシン污染状況についてみると, ダイオ キシンは, 発生源から大気中に放出され, 土壤, 河川, 海水等の環境を污染し, さらにそこで生育する動植物に 取り込まれる.これらの動植物の多くは, 人間の食料之 なりそれと一緒にヒトの体内に入り込む。

厚生省が実施した平成 8 年度の食品中ダイオキシン類 等污染実態調査によれば，体重 $50 \mathrm{~kg}$ の成人が 1 日に掑 取する量は, ダイオキシン類として平均 $0.63 \mathrm{pg} / \mathrm{kg} / \mathrm{day}$ と推定している．同時に測定されたュプラナーPCBの 平均値 $0.97 \mathrm{pg} / \mathrm{kg} / \mathrm{day}$ と合計して $1.6 \mathrm{pg} / \mathrm{kg} /$ day と計算 され，WHOのTDI に近い値に収まっている（表2）。 
日本食生活学会志 Vol.10 No.1（1999）

表 2 のデータから, 食品のらち最もダイオキンン污染 を受けている可能性のあるものとして，魚介類が挙げら れる. 発生源から放出されたダイオキシンは, 大気, 土 壤を経由して河川や海水を污染し，そこに生息する魚介 類に取り込まれ，脂肪組織に蓄兄られる.

食品と一緒に取り込ま机るダイオキシン量が最も多い ことは明らかである。その原因がごみ焼却等にあること から, 発生源におけるダイオキシンの発生量を削減し, 環境中への放出を防止することが食品の安全確保を含を ヒトの健康確保につながる。現在, 国に招いて厚生省と 環境庁が中心になってダイオキシン対策を進めており， 1996年を100とした場合 5 年後にその $14 \%$ 亿削減できる 見通しを立てている。

ダイオキシンを例に述べてきたが，POPsは基本的に 同様の挙動を示すため，1995年11月 UNEP（国連環境 計画）の主導で，「陸上活動からの海洋環境保護に関す る世界行動計画」において12種の POPs について環境 負荷抑制のため，2000年までに法的拘束力を持つ文書を 採択することで国際的合意がなされている。いずれも内 分泌攪乱化学物質と指摘されているものでせる.

\section{(2) プラスチック原料および工業用化学物質}

内分泌かく乱物質としてりストされた化学物質の国内 生産量についてみるとスチレン150万トン, DEHP（フ タル酸ジェチルヘキシル）26万トン，ビスフェノール A 25万トンであり，いずれも20万トン以上の使用量で，一 般化学物質として深く生活に密着している.

ビスフェノール $\mathrm{A}$ は, プラスチックのポリカーボネー トとエポキン樹脂の合成原料である。 また，歯科材料の シーラント，缶詰の内側のコーティングに用いられてい る、これらを高温に加熱するとカーボネートが加水分解 して, あるいは未反応のビスフェノール Aが溶出してく る.

我が国の食品衛生法では, ビスフェノール A の溶出基 準値を2.5ppm と定めている。これは，ラットの長期毒 性試験に沶いて毒性のあらわれる最小投与量を50 $\mathrm{mg} / \mathrm{kg}$ 体重/日とし, それに安全係数 1000 分の 1 をか けた $0.05 \mathrm{mg} / \mathrm{kg}$ 体重/日といら許容摂取量に基づいて いる.

魚や肉類などの入つた食缶や飲料缶の内側は，金属の 溶出などを防ぐためにエポキン系塗料でューティングさ れている.このエポキシ系塗料から，ビスフェノールA が溶出（9-60ppb）することが報告された。同じ缶でも 加圧・加熱殺菌（レトルト）でビスフェノール Aが高く 溶出する (表 3 ).
表 3 ビスフェノールAに関するデータ

\begin{tabular}{|c|c|c|c|}
\hline 試 料 & 溶出条件 & 濃度 & 備 \\
\hline 食器 & $\begin{array}{l}\mathrm{n} \cdots \text { ヘプン } 25^{\circ} \mathrm{C} \\
60 \text { 分 }\end{array}$ & 28. 8-39.1ppb & \multirow[t]{2}{*}{$\begin{array}{l}\text { 河村葉子ら（国立 } \\
\text { 医薬品食品衛生研 } \\
\text { 究所） }\end{array}$} \\
\hline 未使用食器 & 水, $95^{\circ} \mathrm{C} 30$ 分 & $\begin{array}{l}60 \mathrm{ppb} \text { (煮沸後 } 1 \\
\mathrm{ppb} \text { 以下) }\end{array}$ & \\
\hline 未使用食器 & 水, $95^{\circ} \mathrm{C} 30$ 分 & $6 \mathrm{ppb}$ & \multirow[t]{4}{*}{$\begin{array}{l}\text { 環境庁企画調整局 } \\
\text { 環境保全活動推進 } \\
\text { 室 }\end{array}$} \\
\hline 15回洗浄食器 & $4 \%$ 酶酸, $95^{\circ} \mathrm{C} 30$ 分 & $\begin{array}{l}7 \mathrm{ppb}(15 \text { 回までは } \\
<5 \mathrm{ppb}\end{array}$ & \\
\hline 50 回洗浄食器 & - & 最大 $64 \mathrm{ppb}$ & \\
\hline 100 回洗浄食器 & - & $180 \mathrm{ppb}$ & \\
\hline 食器, 䚾乳瓶等 & $\begin{array}{l}67 \text { 検体から2検体 } \\
\text { 検出 }\end{array}$ & $\begin{array}{l}0.18 \mathrm{ppm}, 0.12 \\
\mathrm{ppm}\end{array}$ & 都立衛生研究所 \\
\hline \multirow[t]{2}{*}{ ほ乳瓶 } & $26^{\circ} \mathrm{C}$ & $<0.2 \mathrm{ppb}$ & $\begin{array}{l}\text { 横浜国立大学環境 } \\
\text { 科学研究センター- }\end{array}$ \\
\hline & $95^{\circ} \mathrm{C}$ & $3.1 \sim 5.5 \mathrm{ppb}$ & \\
\hline 缶詰 & $125^{\circ} \mathrm{C} 30$ 分 & $\begin{array}{l}22.9 \mu \mathrm{g} / \text { 缶, } 18.6 \\
\mu \mathrm{g} / \text { 缶 }\end{array}$ & $\begin{array}{l}\text { Environ. Health } \\
\text { Perspective, 103, } \\
1995\end{array}$ \\
\hline $\begin{array}{l}\text { 塩化ビニール製排 } \\
\text { 水ホース, 台所用 } \\
\text { 手袋, 電源コード, } \\
\text { 八ウス用シート, } \\
\text { 人形 }\end{array}$ & 水に14日間浸漬 & $0.04 \sim 38.1 \mathrm{ppm}$ & 国立環境研究所 \\
\hline 廃棄物埋め立て地 & 浸出水 & $\begin{array}{l}61 \mathrm{ppb} / \text { 年中央濃 } \\
\text { 度値 }\end{array}$ & 国立環境研究所 \\
\hline
\end{tabular}

最近では,ビスフェノールAの溶出を少なくしたポリ エステル系フィルムを使用したスチール缶も出ている.

これまでビスフェノール A は光によって数時間で分解 され，環境中で速やかに微生物分解を受けることから， あまり問題視されていなかった，最近の報告では, ヒト の臍帯からビスフェノールAが極微量検出されたり, 廃 棄物からの浸出液中にビスフェノール Aが年間を通じて 浸出水に検出されている.臍帯から検出されるといらこ とは, 母親の胎艋を通り抜け, 胎児に供給されているこ とを示唆し, 環境中に打いても廃棄物が供給源となり常 飞河川に流出する可能性を示唆している.

\section{4. 行政の対応}

内分泌かく乱物質問題がマスコミ等で連日取り上げら れる中, 政府は平成 10 年度内分泌かく乱物質関係で総額 約 120 億円を投じている.表 4 に各省庁の平成 10 年度内分 
泌擤乱化学物質関連の事業をリストした。これら関係 7 省に労働省を加えて「内分泌かく乱化学物質問題関係省 庁担当社連絡会議」を作り省庁間の連携を強化している.

\section{5. 評価法について}

現在, 世に出ている化学物質の数は約 8 万種といわれ ている.内分泌攪乱化学物質かどらかをどのように評価 寸るのであろらか？

米国では食品品質保護法（FQPA）拈よび安全领料水 法（SDWA）において, 環境保護庁（EPA）が適切に 評価された試験系を用いてスクリーニングプログラムを 開発することを定めている.さらに1998年 8 月にプログ ラムを実行に移し, 使用量の多い約 15,000 種の化学物質 について評価し2000年 8 月に議会報告するように求めて いる. EPAは内分泌かく乱物質のスクリーニングと検 查方法に関する諮問委員会（EDSTAC）を設置した。

EDSTACのスクリーニングおよび検査計画案を図 1 に 示した.

スクリーニング等の実施方法は毒性物質規制法（TS CA）に登録のある 86,000 化合物について既存の情報を もとに 4 つに分類した上でハイスループット事前スク リーニング (HTPS), 第 1 段階スクリーニング (TIS), 第 2 段階試験（T2T）, 危害分析を実施するこ とが提案されている.

八イスループット事前スクリーニング（HTPS）の目 的は比較的短時間に, 多くの化学物質について, 予備的 な生物活性情報を得ることにある. 具体的には土スト口 ゲン，アンドロゲン及び甲状腺のレセプターに対する作 用を検出するため転写活性とレセプタ一結合親和性を指 標とした試験管内試験を自動化された分析装置（ハイス ループット）を用いて，約 15,000 物質について事前スク リーニングする.

第 1 段階スクリーニング (TIS) の目的は, 内分泌か く乱作用を有する可能性のある物質であるか否かを分類 するため必要最小，かつ十分なデータを得る事である.

TIS はエストロゲン, アンドロゲン, 甲状腺ホルモン に関連する作用を強める/模倣する／抑制する影響を検 出するよらにデザインされた一連の試験からなる。これ らの試験系で陽性と評価された物質は，より高いプライ オリティで第 2 段階試験（T2T）が行われる.

第 2 段階試験（T2T）の目的は, ヒ上と野生生物に 打ける内分泌かく乱の性質, 可能性, 用量一反応関係を 性格付けることである. 化学物質が内分泌かく乱物質で あるかどらかを決定するとともに，その作用が直接か間
表 4 平成10年度の行政の動き

\begin{tabular}{|c|c|c|c|}
\hline 環侍 & 厚生省 & 農林水産省 & その他省庁 \\
\hline 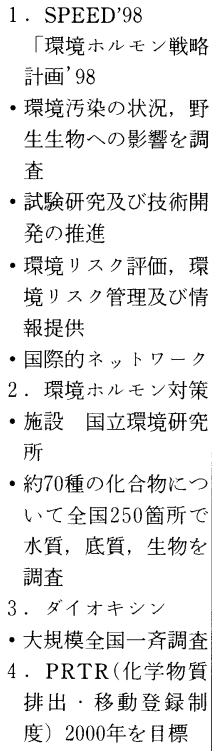 & 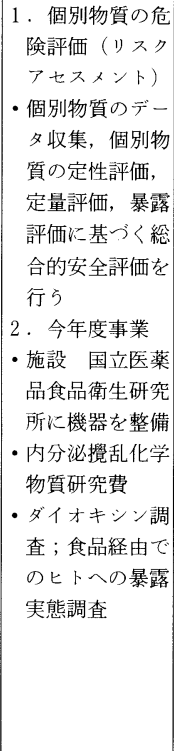 & $\begin{array}{l}\text { 1. 設備 } \\
\text { • 農業環境技 } \\
\text { 術研究所や } \\
\text { 食品総合研 } \\
\text { 究所など } 3 \\
\text { 箇所に, 農 } \\
\text { ·食・水分 } \\
\text { 野で環境木 } \\
\text { ルモン影響 } \\
\text { 評価のため } \\
2 \text {. 農薬の繁 } \\
\text { 殖毒性評価 } \\
\text { の調査研究 } \\
\text { ・新たに農薬 } \\
\text { の安全性評 } \\
\text { 洒項目に追 } \\
\text { 加すべきか } \\
\text { どらか検討 } \\
\text { する. }\end{array}$ & $\begin{array}{l}\text { 1. 通産省 } \\
\text { •工業技術院資源 } \\
\text { 環境技術総合研 } \\
\text { 究所の改修 } \\
\text { • 厚生省と共同で } \\
\text { HTPS (高速大 } \\
\text { 量自動分析法) } \\
\text { 在開発 } \\
\text { 2. 科技打 } \\
\text { ・公募型研究事業 } \\
\text { で環境ホルモン } \\
\text { 研究を強化 } \\
3 \text {. 文部省 } \\
\text { ・医療廃棄物や実 } \\
\text { 験動物処理時の } \\
\text { ダイオキシン発 } \\
\text { 生対策 } \\
4 \text {. 建設省 } \\
\text { ・下水処理場の実 } \\
\text { 態調査 } \\
5 \text {. 労働省 } \\
\text { ・作業環境につい } \\
\text { て }\end{array}$ \\
\hline
\end{tabular}

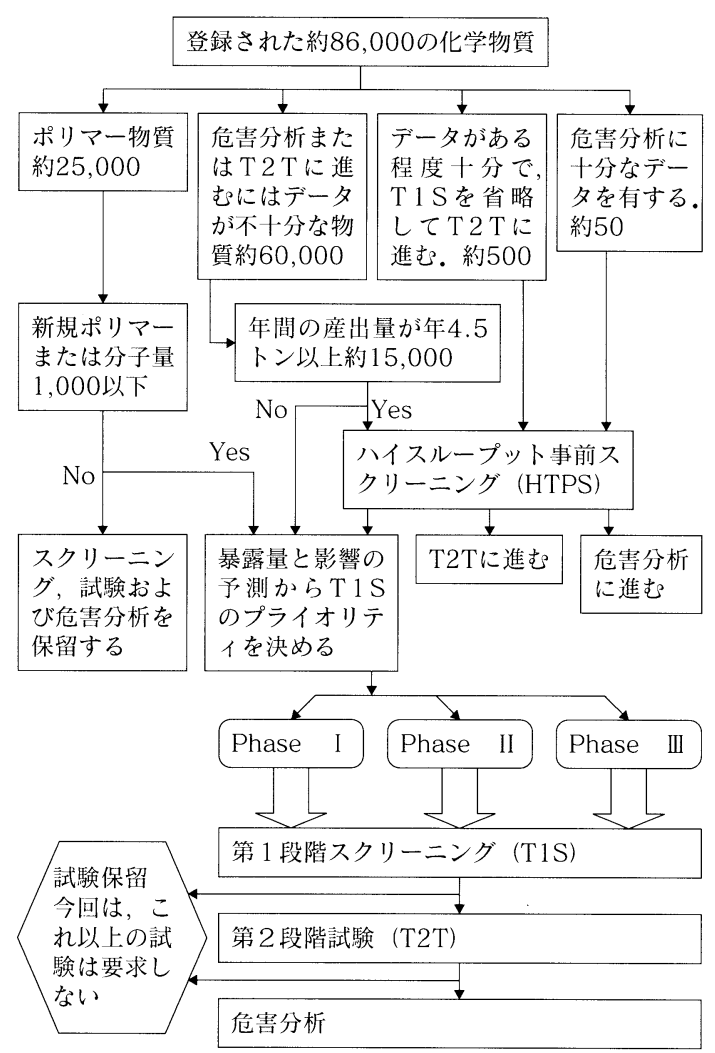

図 1 EDSTAC の初期スクリーニング 
接かを検討する。また，人及び野生生物に対するハザー ドアセスメント（危害分析）を行ら上で有用な情報を得 る．陽性と評価された場合には，その物質について危害 分析が行われる。

\section{6 . 今後の課題}

現状は,科学的知見があまりにも不十分な状態にある。 IPCS の子供の環境衛生に関するグループリーダによる 1997年宣言では “幼児や子供はこれらの污染物質の潜在 的影響を受ける可能性が高い。また，子宮内でまたは母 乳を通して，さらに環境中で内分泌かく乱物質の暴露を 受ける恐れがある.”と述べている。ささら OECD は，

（i ）情報を提供し活動を調整する.（ii）内分泌かく 乱物質の検出に関する新たなテスト指針を作成し，既存 のテスト指針の見直しを行うこと.（iii）加盟国間に拉 いて，内分泌かく乱物質に関する危害及びリスクの特性 決定並びに評価手法の整合性をはかることを目的として いる.

研究すべき項目，調査研究が必要な分野は多岐にわた っている. IPCS は研究の方向について以下のポイント を指摘している。

・エンドポイントを環境生物とヒトを分けて考える.

- 内分泌かく乱作用は包括的で, 多くの器官に関与す る。多様性がある。

・用量一反応曲線の形状が複数にわたっている．影響 するにはどの程度の用量が必要か？

・影響評価において，複数化学物質の混合物の暴露が あり,さらにその相互作用（添加，相乗，増強，拮 抗）が考えられる.

・天然物質と内因性ホルモンが相互作用する
これら複雑に絡まった問題をひとつひとつ解決するた めに，いま，やっと研究が始まったばかりである.

\section{文献}

1）外因性内分泌かく乱化学物質問題に関する研究班中間 報告 1997.7

2）環境内分泌かく乱作用に関する特別報告; 影響の評価 々分析 米国 EPA 1998.3. 社団法人 日本化学物質安 全・情報センター

3）平成 8 年度通産省委託調査「内分泌（エンドクリン） 系に作用する化学物質に関する調査」

4）第22回 日本環境化学会講演会予稿集「環境中のホル モン様化学物質に関する講演会」1997.9.18 日本環境化 学会

5）井口泰泉：環境ホルモンの何が問題か 中央公論 1998.5

6）厚生省：内分泌かく乱化学物質の健康影響に関する検 討会議事次第 $1998.4 .28 ， 1998.5 .27 ， 1998.7 .1$

7）環境庁：外因性内意分泌かく乱化学物質問題への環境 庁の対応方針について一環境ホルモン戦略計画 SPEED'981998.5.7

8） T、コルボーンら（長尾訳）：奪われし未来 翔泳社 1997

9）デボラ・キャドバリー（古草訳）：メス化する自然 集英社 1998

10）WWF ホームページリスト; http://www.wwfcanada. og/hormone-disruptors/list.html

11）国立医薬品食品衛生研究所：環境に関寸る情報（環境 ホルモン) ILLINOIS EPA ENDOCRINE DISRUPTEERS STRATEGY

12) Lawrence H. Keith, Environmental Endocrine Disruptors, John Wiley \& Sons, Inc. 1997

13）厚生省：平成 8 年度 食品中のダイオキシン類等污染 実態調查報告書

14）内分泌かく乱化学物質問題をめぐる生活と食の安全に ついての国際シンポジウム講演要旨集 日本食品化学学会 (1998) 